\title{
PULMONARY IRRITATION AFTER INHALATION EXPOSURE TO BENZALKONIUM CHLORIDE IN RATS
}

\section{RADOSŁAW ŚWIERCZ, TADEUSZ HAŁATEK, WOJCIECH WĄSOWICZ, BARBARA KUR, ZOFIA GRZELIŃSKA, and WANDA MAJCHEREK}

${ }^{1}$ Nofer Institute of Occupational Medicine, Łódź, Poland

Department of Toxicology and Carcinogenesis

${ }^{2}$ Nofer Institute of Occupational Medicine, Łódź, Poland

Department of Immunotoxicology

\begin{abstract}
Background: Benzalkonium chloride (BAC) is a quaternary ammonium compound (QAC) with a $\mathrm{C}_{8}$ to $\mathrm{C}_{18}$ chain length of alkyl groups. Since BAC exerts toxic effects on microorganisms, it has been used as an effective germicide and preservative, mostly in cosmetic industry and medicine. However, the toxic potential of BAC may be hazardous to humans, due to the common use of preparations containing BAC as a preservative. Material and Methods: To assess the possible toxic effects of $\mathrm{BAC}$, two-stage experiments were performed on female Wistar rats. At first, $\mathrm{LC}_{50}$ after a single exposure to $\mathrm{BAC}$ aerosol was determined. Then, the animals were exposed to BAC aerosol at $30 \mathrm{mg} / \mathrm{m}^{3}$ for $6 \mathrm{~h}$, and for 3 days $(6 \mathrm{~h} /$ day). The controls were unexposed rats. Directly after BAC exposure and $18 \mathrm{~h}$ afterwards, BALF concentrations were measured of total protein, Clara cell protein, matrix metalloproteinase-9 (MMP-9), hyaluronic acid (HA), immunoglobulin E (IgE) and cytokines (TF- $\alpha$, IL- 6 and MIP-20), lactate dehydrogenase (LDH) and GSH-S-transferase (GST). Results: The LC $_{50}$ value for exposed rats was ca. $53 \mathrm{mg} \mathrm{BAC} \mathrm{in} \mathrm{m}^{3}$ air for $4 \mathrm{~h}$. All the rats survived single and repeated inhalation exposure to $30 \mathrm{mg} / \mathrm{m}^{3}$ BAC. After single and repeated exposure, lung weight, total protein, HA and LDH activity in BALF of exposed rats were higher than in controls while CC16 levels were decreased. A significantly higher BALF concentration of IL-6 and IgE was noted in animals exposed to single and repeated doses. BALF concentrations of MMP-9, TNF- $\alpha$, and MIP-2 in exposed rats were similar to those in control animals. Conclusion: BAC may be classified to class I acute inhalation toxicity. It showed a strong inflammatory and irritant activity on the lungs after 6h inhalation and stimulated dynamic patterns of IL-6 and $\mathrm{IgE}$ production and protein infiltration from blood vessels to BALF. Continued exposure resulted in cellular destruction, a statistically significant increase in LDH activity and a continuous decrease in CC16 concentration in BALF.
\end{abstract}

Key words:

Benzalkonium chloride, Rats, Inhalation, Clara cell protein, Immunoglobulin E, Interleukin 6

\section{INTRODUCTION}

Benzalkonium chloride (BAC) is a mixture of organic chemicals belonging to the quaternary ammonium compounds (QAC). BAC consists of alkylbenzyl dimethylammonium chlorides with alkyl chain lengths varying from $\mathrm{C}_{8} \mathrm{H}_{17}$ to $\mathrm{C}_{18} \mathrm{H}_{37}$ (Fig. 1). Structurally, BAC comprises a polar hydrophilic group and a non-polar lipophilic hydrocarbon radical. BAC is a surface-active agent belonging to the cationic detergent category, where the hydrophilic group is a cation [1]. Owing to their chemical structure, the ternary ammonium compounds inhibit bacterial enzymatic processes [2]. The bactericidal characteristics of BAC was for the first time applied in the USA, after the American College of Toxicology had issued a positive opinion on its use as a bactericide [3]. Up to the present day, the

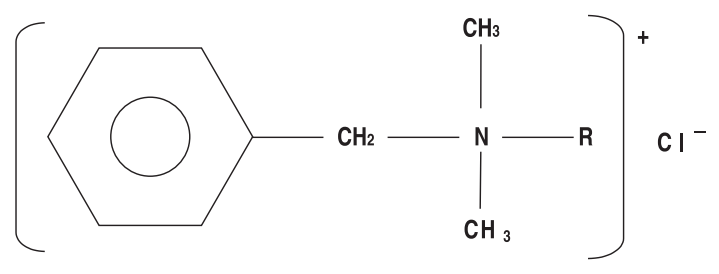

Fig. 1. Chemical formula of benzalkonium chloride (BAC). $\mathrm{R}=$ contains $\mathrm{C}_{8} \mathrm{H}_{17}$ and $\mathrm{C}_{18} \mathrm{H}_{37}$ homologues.

Received: November 20, 2007. Accepted: November 30, 2007.

Address reprint requests to R. Świercz, PhD, Department of Toxicology and Carcinogenesis, Nofer Institute of Occupational Medicine, św. Teresy 8, 91-348 Łódź, Poland (e-mail: radek@imp.lodz.pl). 
bactericidal properties of BAC have been extensively used worldwide, mostly in drugs and cosmetics where BAC has been added as a preservative [4-6].

Animal experiments have revealed that BAC is a compound showing strong toxic effects to laboratory animals. Experimental median lethal doses $\left(\mathrm{LD}_{50}\right)$ for BAC administered intragastrically ranged from 234 do $445 \mathrm{mg} / \mathrm{kg}$ for the rat and the respective value for the guinea pig was $200 \mathrm{mg} / \mathrm{kg}$ [7-9]. Animals that had survived a single intragastric dose of $250 \mathrm{mg} / \mathrm{kg}$ BAC showed alveolar changes indicative of an inflammatory process [10,11]. Intravenous or intra-aortal administration of $15 \mathrm{mg} / \mathrm{kg}$ BAC to rats was fatal to $20 \%$ of the animals. A $30-\sec$ to 40 -sec respiratory arrest was recorded in the survivors [10]. Recent report has shown that BAC may cause elevated immune response in mice. The authors suggest that BAC exposure may in part affect the pulmonary function by modulating the immuno-inflammatory response $[12,13]$.

It should be stressed that in some asthmatic children, inhalatory treatment with BAC-containing preparations may cause bronchospasm. Therefore, the American Academy of Pediatrics suggested that for safety reasons BAC should be removed from the preparations used to treat asthmatic patients. In England, BAC is no longer added to solutions intended for inhalatory treatment, due to its adverse effect on the bronchi [3].

The present study was conducted to assess the toxic activity of BAC aerosol on laboratory animals under conditions of single and repeated inhalation exposure. Markers of a direct damage to lung tissue (CC16, $\mathrm{LDH}$, total protein) and compounds that may indicate an inflammatory condition (TNF- $\alpha$, IL-6, MIP-2) or repair processes in the damaged cells (MM-9) were determined to investigate the adverse effects of BAC on the lungs of laboratory animals $[12,14]$.

\section{MATERIALS AND METHODS}

\section{Animals}

Female outbred Imp: Wist Wistar rats, aged 2 to 3 months, that were obtained from the breeding farm of the Nofer Institute of Occupational Medicine, Łódź, Poland, were used in the experiment. At each stage of the study, groups of five animals were investigated: the exposed animals as the study group and unexposed ones as the controls. During the testing, both the groups were kept in exposure chambers but the control rats inhaled atmospheric air; other environmental conditions: temperature, humidity, and food and water intake were the same for the two groups.

\section{Chemicals}

The study groups were exposed to BAC (Fluka, CAS no. 8001-54-5, purity $\geq 95 \%$ ) as an aerosol.

\section{Inhalation exposure}

Figure 2 is a diagram showing the animal exposure system. The chemical to be tested was injected into exposure chamber with a dynamic air flow to ensure 15 air changes per hour, so that the rat's head/nose would be directly exposed to BAC as an aqueous aerosol. The system used to produce BAC aerosol comprised a Harvard 950A Pump and an atomiser. BAC concentration in the chamber was monitored by HPLC $[10,15]$. Air samples collected in the chamber were filtered on FIPRO-37 polypropylene filter. $\mathrm{BAC}$ was then desorbed from the filter in the mobile phase and analyzed by liquid chromatography. A Waters liquid chromatograph (2690 Integrity System) with a Waters 996 UV-VIS detector was used for the quantitative determinations of BAC. A $100 \mu$ sample was injected into a YMCPack CN $(250 \times 4.6$ mm I.D, S-5 $\mu \mathrm{m}, 12 \mathrm{~nm})$ column, with a mixture $(52: 48 \mathrm{v} / \mathrm{v})$ of $0.1 \mathrm{~mol} \mathrm{pH}=5.0$ sodium acetate and acetonitrile as the mobile phase. The measurement was performed at $250 \mathrm{~nm}$ wavelength.

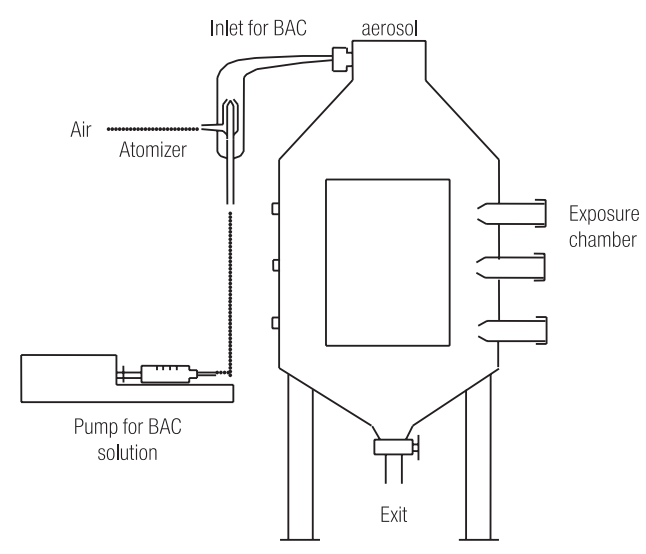

Fig. 2. Technical scheme of nose-only inhalation exposure conditions for toxicity testing of BAC aerosol. 


\section{Experimental design}

The local Biomedical Ethics Committee has approved the study protocol (Opinion No. Ł/BD/247). The study, designed to asses BAC toxicity to laboratory animals was performed in two stages. The first stage was designed to determine the median lethal concentration for BAC after head/ nose inhalation exposure. Two groups of rats (5 per group) were used at that stage. One of the groups was exposed to the maximum concentration of BAC $\left(52.84 \mathrm{mg} / \mathrm{m}^{3}\right)$ that could be generated in exposure chamber. The other group was exposed to a lower concentration $\left(37.64 \mathrm{mg} / \mathrm{m}^{3}\right)$. For both the groups, the exposure time was 4 hours. After termination of exposure, the animals were observed for 14 days. The aim of the second stage was to assess the pneumotoxic effect after a single $(6 \mathrm{~h})$ and repeated (3 days, $6 \mathrm{~h} /$ day) inhalation exposure, during which BAC concentration in exposure chamber was $50 \%$ lower than the $\mathrm{LC}_{50}$ value. Bronchoalveolar lavage fluid (BALF) was collected from the exposed and control animals at two time-points: immediately after termination of exposure and $18 \mathrm{~h}$ afterwards. The rats were anaesthetized by an intraperitoneal injection of pentobarbital sodium at $50 \mathrm{mg} / \mathrm{kg}$ body weight and their lungs were lavaged with $2 \times 5 \mathrm{ml}$ of $0.9 \% \mathrm{NaCl}$ solution. BALF was collected and centrifuged at $200 \mathrm{~g}$ at $4^{\circ} \mathrm{C}$ for $10 \mathrm{~min}$. The supernatant was used for biochemistry. Clara cell protein (CC16) was determined by latex immunoassay [16]. Specific rabbit antibodies against CC16 and a standard for $\mathrm{CC16}$, based on the purified protein, were obtained as described elsewhere [17]. Hyaluronic acid (HA) was measured in non-concentrated BALF by enzymatic-immunoassay (ELISA) kit, including hyaluronic acid binding protein (HABP) capture molecule (Chungai-test, Japan). Lactate dehydrogenase (LDH) activity [18] and the levels of matrix metalloproteinase-9 (MMP-9) (Amersham Biosciences), tumor necrosis factor (TNF- $\alpha$ ), interleukin 6 (IL-6), macrophage inflammatory protein (MIP)-2 (Biosource) and IgE were measured in BALF using the ELISA kit. GSH-S-transferase (GST) (EC. 2.5.1.18) in postmitochondrial supernatants of rat lung was assessed with 1-chloro-2,4-dinitrobenzene (CDNB) [19]. The quantity of $\mathrm{CDNB}$ (nmol) reacting during one minute was regarded as the unit $(\mathrm{u})$ of measurement.

\section{Statistical analysis}

The results were compared using the Kruskall-Wallis oneway ANOVA. Scheffe's test was used for detailed, multiple comparisons. Differences were regarded as significant when the probability of the null hypothesis was $<0.05$.

\section{RESULTS}

At the first stage of the experiment, two rats did not survive the 14-day observation period. Out of the 5 rats, $2(40 \%)$ died within the first $24 \mathrm{~h}$ period after $4 \mathrm{~h}$ exposure to $52.84 \mathrm{mg} / \mathrm{m}^{3}$

Table 1. Body weight and food intake in rats subjected to a single exposure to BAC

\begin{tabular}{|c|c|c|c|c|}
\hline \multirow{2}{*}{$\begin{array}{c}\text { BAC concentration } \\
\left(\mathrm{mg} / \mathrm{m}^{3} \pm \mathrm{SD}\right)\end{array}$} & \multirow{2}{*}{ Parameter } & \multicolumn{3}{|c|}{ Day } \\
\hline & & 1 & 7 & 14 \\
\hline \multirow[t]{3}{*}{$52.84 \pm 12.56$} & $\begin{array}{l}\text { Body weight } \\
(\mathrm{g} \pm \mathrm{SD})\end{array}$ & $182 \pm 9.80$ & $201.70 \pm 12.60$ & $206.70 \pm 12.60$ \\
\hline & Changes in b.w. $(g \pm S D)$ & & $16.70^{\mathrm{a}} \pm 2.90$ & $5.00^{\mathrm{b}} \pm 0.00$ \\
\hline & $\begin{array}{l}\text { Food intake } \\
(\mathrm{g} / \mathrm{rat} / \text { week })\end{array}$ & & 117 & 100 \\
\hline \multirow[t]{3}{*}{$37.64 \pm 7.78$} & $\begin{array}{l}\text { Body weight } \\
(\mathrm{g} \pm \mathrm{SD})\end{array}$ & $217 \pm 5.70$ & $226 \pm 7.40$ & $234 \pm 5.50$ \\
\hline & Changes in b.w. $(g \pm S D)$ & & $9 \pm 4.20$ & $8 \pm 4.50$ \\
\hline & $\begin{array}{l}\text { Food intake } \\
(\mathrm{g} / \mathrm{rat} / \text { week })\end{array}$ & & 90 & 135 \\
\hline
\end{tabular}

${ }^{a}$ Different from the value recorded at the onset of experiment.

${ }^{b}$ Different from the value recorded within the first week of observation. 
Table 2. Body weight, lung weight/100 g b.w., CC16 and total protein concentration, HA and LDH activity in BALF, GST in the lung, and concentrations of matrix metalloproteinase-9 (MMP-9), tumor necrosis factor (TNF- $\alpha$ ), interleukin 6 (IL-6), macrophage inflammatory protein (MIP)-2 and IgE in BALF of control rats and rats exposed for $6 \mathrm{~h}$ to $28.0( \pm 6.0) \mathrm{mg}( \pm \mathrm{SD}) \mathrm{BAC} / \mathrm{m}^{3}$

\begin{tabular}{|c|c|c|c|}
\hline \multirow[t]{2}{*}{ Parameter } & \multirow[t]{2}{*}{ Control } & \multicolumn{2}{|c|}{$\begin{array}{l}\text { Time point } \\
\text { (h) }\end{array}$} \\
\hline & & 0 & 18 \\
\hline Body weight (g) & $188 \pm 5.70$ & $176 \pm 8.20$ & $176 \pm 5.50$ \\
\hline Lung weight $/ 100 \mathrm{~g}$ b.w. & $0.77 \pm 0.08$ & $1.01 \pm 0.14^{*}$ & $0.89 \pm 0.13$ \\
\hline Total protein $(\mathrm{g} / \mathrm{l})$ & $0.47 \pm 0.16$ & $8.62 \pm 1.82 * * *$ & $6.39 \pm 2.74 *$ \\
\hline CC16 $(\mu \mathrm{g} / \mathrm{l})$ & $12.30 \pm 4$ & $2.25 \pm 1.24 * * *$ & $5.37 \pm 0.53^{*}$ \\
\hline $\mathrm{HA}(\mu \mathrm{g} / \mathrm{l})$ & $8 \pm 6.81$ & $34.50 \pm 2.50 *$ & $14.75 \pm 9.58$ \\
\hline LDH (U/l) & $109 \pm 39$ & $275 \pm 100^{* *}$ & $205 \pm 40 * *$ \\
\hline GST (u/mg protein) & $389 \pm 70$ & $351 \pm 35$ & $362 \pm 123$ \\
\hline MMP-9 (ng/ml) & $0.89 \pm 0.13$ & $0.79 \pm 0.03$ & $0.84 \pm 0.08$ \\
\hline TNF- $\alpha(\mathrm{pg} / \mathrm{ml})$ & $24.30 \pm 23.60$ & $26.50 \pm 18.60$ & $64.10 \pm 26^{*}$ \\
\hline IL-6 (pg/ml) & $49.20 \pm 22.60$ & $910 \pm 197^{* * *}$ & $138 \pm 27$ \\
\hline MIP-2 (pg/ml) & $322 \pm 119$ & $452 \pm 113$ & $259 \pm 100$ \\
\hline $\operatorname{IgE}(\mathrm{ng} / \mathrm{ml})$ & $6.28 \pm 3.32$ & $117 \pm 55^{*}$ & $140 \pm 97^{*}$ \\
\hline
\end{tabular}

$*, * * * * *$ Significantly different from control at $\mathrm{p}<0.05, \mathrm{p}<0.01$, and $\mathrm{p}<0.001$, respectively. Results expressed as mean \pm SD.

Table 3. Body weight, lung weight/100 g b.w., CC16 and total protein concentration, HA and LDH activity in BALF, GST in lung, and concentrations of matrix metalloproteinase-9 (MMP-9), tumor necrosis factor (TNF- $\alpha$ ), interleukin 6 (IL-6), macrophage inflammatory protein (MIP)-2 and IgE in BALF of control rats and rats exposed for 3 days $(6 \mathrm{~h} /$ day $)$ to $30.5( \pm 4.2) \mathrm{mg}( \pm \mathrm{SD}) \mathrm{BAC} / \mathrm{m}^{3}$

\begin{tabular}{|c|c|c|c|}
\hline \multirow[t]{2}{*}{ Parameter } & \multirow[t]{2}{*}{ Control } & \multicolumn{2}{|c|}{$\begin{array}{l}\text { Time point } \\
\text { (h) }\end{array}$} \\
\hline & & 0 & 18 \\
\hline Body weight (g) & $191 \pm 7.40$ & $171 \pm 10.80$ & $180 \pm 10$ \\
\hline Lung weight $/ 100 \mathrm{~g}$ b.w. & $0.84 \pm 0.16$ & $1.23 \pm 0.07^{* *}$ & $1.03 \pm 0.06$ \\
\hline Total protein $(\mathrm{g} / \mathrm{l})$ & $0.18 \pm 0.64$ & $1.89 \pm 0.66^{* * *}$ & $0.39 \pm 0.15^{*}$ \\
\hline $\mathrm{CC} 16(\mu \mathrm{g} / \mathrm{l})$ & $8.39 \pm 1.44$ & $1.35 \pm 0.30 * * *$ & $2.17 \pm 0.44$ \\
\hline $\mathrm{HA}(\mu \mathrm{g} / \mathrm{l})$ & $11.50 \pm 1.30$ & $21.10 \pm 5.70$ & $16.60 \pm 11.70$ \\
\hline $\mathrm{LDH}(\mathrm{U} / \mathrm{l})$ & $124 \pm 32$ & $457 \pm 51^{* *}$ & $207 \pm 44$ \\
\hline GST (u/mg protein) & $133 \pm 15$ & $123 \pm 25$ & $102 \pm 23^{*}$ \\
\hline MMP-9 (ng/ml) & $0.84 \pm 0.10$ & $0.77 \pm 0.03$ & $0.98 \pm 0.19$ \\
\hline TNF- $\alpha(\mathrm{pg} / \mathrm{ml})$ & $20.60 \pm 16.20$ & $50 \pm 43.70$ & $5.78 \pm 3.99$ \\
\hline IL-6 (pg/ml) & $31.50 \pm 18.40$ & $528 \pm 282^{*}$ & $16.2 \pm 15$ \\
\hline MIP-2 (pg/ml) & $297 \pm 231$ & $479 \pm 159$ & $133 \pm 27$ \\
\hline $\operatorname{IgE}(\mathrm{ng} / \mathrm{ml})$ & $3.52 \pm 2.42$ & $14.57 \pm 5.10^{*}$ & $1.58 \pm 0.49$ \\
\hline
\end{tabular}

Abbreviations as in Table 2.

BAC aerosol. The rats exposed to BAC at $37.64 \mathrm{mg} / \mathrm{m}^{3}$, survived the 14-day observation period. In animals that survived the 4 h exposure and 14-day observation, body weight gain and food intake were similar (Table 1). Gross examination of the animals which were necropsied after 14-day observation revealed no pathological changes.

At the second stage, all the rats survived inhalation exposure to BAC aerosol. Table 2 shows the changes in 
lung weight $/ 100 \mathrm{~g} / \mathrm{b}$.w. as well as GST in the lung and other biomarkers in BALF of rats exposed for $6 \mathrm{~h}$ and in respective controls. As regards BAC-exposed group, a significant increase was noted in total protein, CC16, $\mathrm{LDH}$ and IgE in BALF both directly after termination of exposure and $18 \mathrm{~h}$ afterwards. Significantly higher IL- 6 and HA concentrations in BALF were found in the exposed group immediately after exposure. Also, higher concentrations of TNF- $\alpha$ in BALF were recorded in the exposed group at the $18 \mathrm{~h}$ time-point. A significant increase in relative lung mass was observed directly after termination of exposure. No significant differences were noted in GST, MMP-9 and MIP-2 levels between the exposed group and the controls. In animals repeatedly exposed to BAC aerosol ( 3 days; $6 \mathrm{~h} /$ day), for most of the biomarkers, the concentration changes were similar to those noted in animals exposed once.

Table 3 shows the changes in lung weight/100 g b.w. as well as GST in lung and other biomarkers in BALF of rats exposed for 3 days $(6 \mathrm{~h} /$ day) to BAC aerosol in relation to the control group. A significant increase in relative lung mass, concentration of total protein, $\mathrm{LDH}$ and $\mathrm{IgE}$ in BALF, and a significant decrease in $\mathrm{CC} 16$ concentration in BALF were recorded at the first time-point among the repeatedly-exposed animals compared to controls. Higher total protein concentration and lower lung GST levels in the exposed animals were detected at the $18 \mathrm{~h}$ time-point. No significant differences in BALF concentrations of IL-6, MIP-2, TNF- $\alpha$ and IgE between the exposed animals and controls were noted $18 \mathrm{~h}$ after exposure (Table 3 ).

\section{DISCUSSION AND CONCLUSIONS}

The results of the preliminary tests indicate that BAC aerosol may be classified to Class I acute inhalation toxicity, i.e. as very toxic under conditions of acute inhalation exposure [20]. The maximum concentration of BAC aerosol $\left(52.84 \mathrm{mg} / \mathrm{m}^{3}\right)$, causing death of $40 \%$ of the animals, was close to the BAC concentration at which the animals survived $\left(37.64 \mathrm{mg} / \mathrm{m}^{3}\right)$. Such a small span between the lethal concentration and the levels which did not bring about fatalities indicates that the $\mathrm{LC}_{50}$ value was close to the maximum BAC concentration that could be generated in the exposure chamber. The experiment designed to assess the pneumotoxic effect of BAC aerosol on laboratory animals revealed that both single and repeated exposure to BAC had a significant influence on the levels of lung biomarkers. In the majority of cases, a similar trend could be observed in this respect. The adverse effect of exposure to BAC aerosol was not found to be time-dependent. Nevertheless, in some cases of repeated exposure, the values of the study parameters were lower (IL-6 and total protein) or higher (LDH), compared with the findings for single exposure to BAC aerosol. However, under the tested conditions, the exposure to $\mathrm{BAC}$ aerosol produced a strong pneumotoxic effect manifested by necrosis of the respiratory cells (increased LDH activity) and lung inflammation (elevated IL-6 concentration) even after a single inhalation exposure. Clara cells producing CC16 protein are a group of cells forming the respiratory lining. The $6 \mathrm{~h}$ inhalation exposure resulted in a dramatic decrease in Clara protein level in BALF. At the $18 \mathrm{~h}$ time-point, CC16 level did not return to the values observed in controls (Table 2). Repeated exposure produced more pronounced decrease in $\mathrm{CC} 16$ concentration and an increase in IL- 6 concentration and LDH activity in BALF, indicating cumulated BAC toxicity. The damage to Clara cells, reflected by decreased concentration of $\mathrm{CC} 16$ showing immunosuppressive and anti-inflammatory activity, accompanied with a significant increase in $\operatorname{IgE}$ level $6 \mathrm{~h}$ and $18 \mathrm{~h}$ after a single exposure to BAC may point to an immuno-inflammatory response $[21,22]$. BAC exposure induces a massive influx of proteins from blood vessels to the intra-alveolar space, which is manifested by increased total protein concentration in BALF. The increase results from the permeability changes in the blood-air barrier which may also account for a decreased CC16 concentration in the bronchiolar lining as a result of CC16 passing into the blood [23-25]. For some of the study parameters, the high inter-individual variability of the concentration levels, which was noted both in the exposed and control groups, directly affected the results of our statistical analyses. An adaptation tendency was found after repeated exposure to $\mathrm{BAC}$ aerosol; the changes in the study parameters were diminishing, which 
was particularly evident $18 \mathrm{~h}$ after termination of the 3-day exposure.

To sum up, inhalation of BAC aerosol induced a strong inflammatory response and a damage to the blood-air barrier. It is reasonable to expect similar pneumotoxic effects in people exposed to high concentrations of BAC aerosol. Inhaling BAC may be dangerous to workers occupationally exposed to this agent, especially those showing a positive skin prick test with BAC [26,27]. Furthermore, recent data suggest that BAC added to preparations intended for inhalatory treatment may pose severe health hazard to asthmatics [28]. For all these reasons, BAC should be used with extreme caution.

\section{ACKNOWLEDGEMENT}

Financial support from the State Committee for Scientific Research (KBN, Warsaw, Poland), Project No. 2 P05D 05728 is gratefully acknowledged.

\section{REFERENCES}

1. Garbuliński T. Veterinary pharmacology. Ed. II. Warszawa: PWRiL; 1980. p. 61-4 [in Polish].

2. Adelson L, Sunshine I. Fatal poisoning due to a cationic detergent of the quaternary ammonium compound type. Am J Clin Pathol 1952;22:656-61.

3. Graf P. Adverse effects of benzalkonium chloride on the nasal mucosa: allergic rhinitis and rhinitis medicamentosa. Clin Ther 1999;21(10):1749-55.

4. Dziennik Ustaw (Law Gazette). Warszawa; 2005. No. 72: item 642 [in Polish].

5. Pharmacopoea Polonica. Ed. VI. Warszawa: PTF; 2002. p. 247 [in Polish].

6. Jurkowska S. Cosmetic materials. Ed. IV. Wrocław: Wyższa Szkoła Fizykoterapii; 2001. p. 308 [in Polish].

7. Alfredson BV, Stiefel JR, Thorp F, Baten WD, Gray ML. Toxicity studies on alkyldimethylbenzylammonium chloride in rats and in dogs. J Am Pharm Assoc 1951;XL(6):263-7.

8. Cummins LM, Kimura ET. Safety evaluation of selenium sulfide antidandruff shampoos. Toxicol Appl Pharmacol 1971;20:89-96.
9. Glaxhuber Ch. Toxicological properties of surfactants. Arch Toxicol 1974;32:245-70.

10. Xue Y, Hieda Y, Kimura K, Takayama K, Fujihara J, Tsujino Y. Kinetic characteristics and toxic effects of benzalkonium chloride following intravascular and oral administration in rats. J Chromatogr B 2004;811:53-8.

11. Xue Y, Hieda Y, Saito Y, Nomura T, Fujihara J, Takayama K, et al. Distribution and disposition of benzalkonium chloride following various routes of administration in rats. Toxicol Lett 2004;148:113-23.

12. Larsen ST, Hansen R, Poulsen OM, Nielsen GD. Adjuvant effect of benzalkonium chloride on the allergen-specific IgE, IgG1 and IgG2a antibody formation in BALB/cJ mice. Basic Clin Pharmaco Toxicol 2004;95:94-6.

13. Pauly A, Brignole-Baudouin F, Guenoun JM, Riancho L, Rat P, Warnet JM, et al. Comparative study of topical anti-allergic eye drops on human conjunctiva-derived cells: responses to histamine and IFN gamma and toxicological profiles. Graefes Arch Clin Exp Ophthalmol 2007;245(4):534-46.

14. Steerenberg PA, Amelsvoort L, Lovik M, Hetland RB, Alberg T, Halatek T, et al. Relation between sources of particulate air pollution and biological effect parameters in samples from four European cities: an exploratory study. Inhal Toxicol 2006;18:333-46.

15. Dutkiewicz-Wilczyńska J, Tautt J, Roman I. Application of the HPLC method for benzalkonium chloride determination in aerosol preparation. J Pharm Biomed Anal 2004;34:909-20.

16. Bernat A, Marchandise FX, Depelchin S, Lauwerys R, Sybille Y. Clara cell protein in serum and bronchoalveolar lavage. Eur Resp J 1992;5:1231-8.

17. Hałatek T, Hermans C, Broeckaert F, Wattiez R, Wiedig M, Toubeau G, et al. Quantification of Clara cell protein in rat and mouse biological fluids using a sensitive immunoassay. Eur Resp J 1998;11:726-33.

18. Bergmeyer HU. Methods of Enzymatic Analysis. Weinheim: Verlag Chemie GmbH; 1974. p. 575-80.

19. Habig W, Pabst M, Jacoby W. Glutathione S-transferase: the first step in mercapturic acid formation. J Biol Chem 1970;249:7130-9.

20. Dziennik Ustaw (Law Gazette). Warszawa; 1997. Annex to No. 105: item 671 [in Polish]. 
21. Dierynck I, Bernard A, Roels H, De Ley M. The human Clara cell protein: biochemical and biological characterisation of a natural immunosuppressor. Mult Scler 1996;1:385-7.

22. Shijubo N, Kawabata I, Sato N, Itoh Y. Clinical aspects of Clara cell 10-kDa protein/ uteroglobin (secretoglobin 1A1). Curr Pharm Des 2003;9:1139-49.

23. Broeckaert F, Bernard A. Clara cell secretory protein (CC16): characteristics and perspectives as lung peripheral biomarker. Clin Exp Allergy 2000;30:469-75.

24. Broeckaert F, Clippe A, Wattiez R, Falmagne P, Bernard A. Lung hyperpermeability, Clara-cell secretory potein (CC16), and susceptibility to ozone of five inbred strains of mice. Inhal Toxicol 2003;15:1209-30.

25. Hałatek T, Opalska B, Rydzyński K, Bernard A. Pulmonary response to methylcyclopentadienyl manganese tricarbonyl treatment in rats: injury and repair evaluation. Histol Histopathol 2006;21:1181-92.

26. Kieć-Świerczyńska M. Causes of allergic occupational dermatitis diagnosed at The Nofer Institute of Occupational Medicine during the last five years. Med Pr 1993;XLIV(6):539-44 [in Polish].

27. Fuchs T, Meinert A, Aberer W, Bahmer FA, Peters KP, Lischka GG, et al. Benzalkonium chloride - a relevant contact allergen or irritant? Results of a multicenter study of the German Contact Allergy Group. Hautarzt 1993;44(11):699-702 [in German].

28. Intorre L, Meucci V, Di Bello D, Monni G, Soldani G, Pretti C. Tolerance of benzalkonium chloride, formalin, malachite green, and potassium permanganate in goldfish and zebrafish. J Am Vet Met Assoc 2007;231(4):590-5. 